\title{
PERLINDUNGAN HUKUM JEMAAH UMRAH DALAM PENYELENGGARAAN PERJALANAN IBADAH UMRAH
}

\author{
Sihabudin Mukhlis \\ Pesantren Mahasiswa Peradaban, Bandung \\ Email : mukhlissihabudin@gmail.com
}

\begin{abstract}
Abstrak
Tulisan ini menjabarkan upaya-upaya perlindungan Jemaah umrah dari tindakan penyelenggara perjalanan ibadah umrah yang merugikan jemaah baik berupa penelantaran jemaah selama perjalanan, penundaan keberangkatan sampai dengan batal dan gagal berangkat.Sebagai dasar hukum, Peraturan Menteri Agama Nomor 8 tahun 2018 tentang Penyelenggaraan perjalanan ibadah Umroh telah memberikan landasan yang memadai bagi perlindungan Jemaah, diantaranya dalam bentuk perlindungan kesehatan, asuransi jiwa, kecelakaan, maupun pengurusan dokumen Jemaah yang hilang selama perjalanan beribadah. Namun, sering keterbatasan dana yang dialami pengelola travel menjadi kendala dalam memberikan perlindungan-perlindungan di atas, akibat harga murah yang diterapkan bagi jemaah dengan memotong biaya asuransi. Di samping itu terdapat pula pengusaha travel yang dari awal tidak beritikad mengasuransikan jemaah umrah. Hal tersebut antara lain karena tidak adanya pengawasan berkala terhadap travel penyelenggara ibadah umrah, serta tindakan bersifat represif, dimana pemerintah bertindak jika terdapat laporan dari Jemaah.
\end{abstract}

\section{Kata Kunci : Travel Umrah, Perlindungan Hukum, Jemaah Umrah}

\section{Pendahuluan}

Melaksanakan ibadah Haji merupakan dambaan setiap orang yang beragama Islam, umat Islam yang berada di seluruh dunia berbondong-bondong untuk pergi Haji, termasuk umat muslim yang ada di Indonesia. Namun dikarenakan semakin banyaknya permintaan untuk keberangkatan haji, sehingga mengakibatkan warga negara Indonesia harus menunggu sampai beberapa tahun. Rasulullah mencontohkan untuk melakukan ibadah lain dengan selain ibadah haji namun dengan pahala yang sama yakni Umrah. ${ }^{1}$

Mulai menjamurnya travel umroh di Indonesia, maka pemerintah Indonesia yang merupakan negara hukum ${ }^{2}$ membuat aturan untuk mengawasi dan mentertibkan penyelenggara perjalanan ibadah haji dan umrah guna memberikan kenyamanan dan keamanan bagi masayarakat. Hal tersebut tertuang dalam Undang-undang No. 13 Tahun 2008 tentang penyelenggaraan Haji serta perubahannya melalui Undang-undang No. 34 Tahun 2009, Peraturan Pemerintah No 79 tahun 2012 tentang Usaha Perasuransian dan Peraturan Menteri Agama (PERMENAG) No 8 tahun 2018 tentang Penyelenggaraan Perjalanan Ibadah Umrah serta aturan-aturan lain semisal Undang-undang No 8 Tahun

\footnotetext{
${ }^{1}$ HR. Bukhori no. 1782 dan H.RMuslim no. 1256 yang berbunyi "Jika Ramadhan tiba, berumrahlah saat itu karena umrah Ramadhan senilai dengan haji."

${ }^{2}$ Undang-undang Dasar Negara Republik Indonesia Tahun 1945, pada pasal 1 ayat (3).
} 
1999 tentang Perlindungan Konsumen (UUPK) yang dapat memperkuat penyelenggaraan perjalanan haji dan umrah tersebut.

Berdasarkan asal 1 ayat 1 UUPK, perlindungan konsumen merupakan semua bentuk upaya yang memberikan jaminan adanya kepastian hukum guna memberi perlindungan kepada konsumen. Kepastian hukum mewakili semua upaya untuk pemberdayaan konsumen guna memperoleh atau menentukan pilihan atas barang dan/ atau jasa sesuai kebutuhannya, serta mecoba membela dan mempertahankan hak-haknya jika dirugikan oleh para pelaku usaha penyedia kebutuhan konsumen ${ }^{3}$. Penerapan ketentuan tersebut antara lain dapat dilihat pada pengaturan tentang kepariwisataan yaitu Undang-undang No. 10 Tahun 2009, dalam Pasal 20 Huruf c menyampaikan bahwa setiap wisatawan (ed. Sebagai pengguna jasa) memiliki hak untuk mendapatkan perlindungan hukum dan keamanan. ${ }^{4}$

Meskipun pemerintah telah mengeluarkan peraturan untuk mengatur sistem penyelenggaraan perjalanan ibadah umrah, ternyata masih banyak travel berizin yang melakukan wanprestasi terhadap Jemaah. Sering terdengar berita baik di media massa maupun media sosial travel yang tidak memenuhi kewajiban terhadap jemaah seperti pembatalan atau penundaan keberangkatan tanpa alasan yang jelas, penelantaran Jemaah baik disaat transit maupun di tempat tujuan, dan lainnya. Penyelenggaraan ibadah umrah kembali menjadi perhatian publik ketika beberapa Penyelenggara Perjalanan Ibadah Umrah (PPIU) seperti First Travel, Solusi Balad Lumampah (SBL), dan Abu Tour gagal memberangkatkan ribuan jemaah umrah ke tanah suci, Makkah dan Madinah. Tiga PPIU ini merupakan biro perjalanan yang memiliki jumlah jemaah umrah yang besar. Jumlah keseluruhan jemaah umrah Abu Tour sebanyak 27.093 orang, sementara jemaah umrah SBL sebesar 12.845 jemaah. Dari dua penyelenggara ibadah umrah tersebut, First Travel memiliki jumlah jemaah umrah terbesar, yaitu sebanyak 58.682 jemaah. $^{5}$

Seharusnya hal tersebut tidak perlu terjadi jika setiap travel sudah melaksanakan kewajiban yang sudah digariskan oleh pemerintah, yakni diantaranya kewajiban travel untuk menyediakan Asuransi bagi Jemaah. Hal tersebut didasarkan pada Peraturan Menteri Agama No.8 tahun 2018 yang mewajibkan pihak PPIU memberikan pelayanan perlindungan kepada Jemaah umrah dan petugas umrah. Selain itu, dalam pasal 20 ayat 1 menyebutkan bahwa untuk memberikan pelayanan perlindungan menjadi tanggung jawab PPIU (penyelenggara perjalanan ibadah Umrah) dengan menjamin asuransi jiwa, kesehatan, serta kecelakaan kepada jemaah umrah.

Dari hasil wawancara yang dilakukan kepada pihak travel dah penelaahan perjanjian antara Jemaah dan travel, masih ditemukan travel yang belum menyediakan asuransi bagi jemaah dengan berbagai alasan yang disampaikan. Adapun travel yang sudah menyediakan asuransi terkadang tidak menyampaikan kepada Jemaah bahwa tedapat fasilitas tersebut yang dapat menjamin kelancaran Jemaah dalam perjalanan ibadah umrah.

\footnotetext{
${ }^{3}$ Aturan tentang Perlindungan Konsumen (Undang-undang No 8 Tahun 1999)

${ }^{4}$ Aturan tentang kepariwisataan (Undang-undang No 10 tahun 2009)

5 jurnalindonesia.co.id/5-kasus-dugaan-penipuan-jemaah-umrah-yang-menghebohkan-publikdi akses jam 16.26 wib 2018
} 


\section{Perlindungan Hukum}

Perlindungan hukum merupakan bagian dari hak yang diberikan oleh Negara kepada warga negaranya. Satijipto Raharjo memberikan pandangannya terhadap perlindungan hukum. Hukum menaungi hak yang dimiliki oleh setiap manusia ketika dirugikan oleh orang lain. Sehingga melalui perlindungan ini seluruh lapisan warga Negara dapat merasakan hak tersedia dari hukum yang berlaku. Hukum bisa ditujukan agar mewujudkan perlindung yang tidak hanya adaptif dan flekibel, namun bisa prediktif dan antisipatif. Dalam fungsinya hukum dibutuhkan oleh masyarakat yang lemah dan belum kuat dari segi sosial, politik dan ekonomi agar terwujud keadialan social. ${ }^{6}$

Setiono menyampaikan pandangannya bahwa perlindungan hukum merupakan sebuah upaya atau tindakan yang dilakukan agar dapat memberikan perlindungan kepada masyarakat, sehingga terhindar dari perbuatan yang tidak baik (kesewenangan) dari para pemilik kekuasaan, demi terwujudnya keamanan, ketertiban dan rasa tenang dari masyarakat agar dapat menikmati martabat menjadi manusia. ${ }^{7}$

Berdasarkan penjelasan di atas dapat disimpulkan bahwa salah satu fungsi hukum yakni melindungi masyarakat dari kejadian yang dapat merugikan dan menderitakan hidupnya dari orang lain, masyarakat maupun para pemegang kekuasaan. Selain itu, hukum berfungsi untuk memberikan keadilan kepada setiap warga negara serta menjadi sarana untuk mewujudkan kesejahteraan bagi seluruh rakyat. taranya: ${ }^{8}$

Adapun cara-cara untuk melakukan perlindungan melalui hal-hal tertentu, dian-

a. Membentuk sebuah aturan (by giving regulation), dengan tujuan agar:

1) Memfasilitasi atau memberikan hak dan kewajiban

2) Adanya jaminan terhadap subyek hukum

b. Menegakan sebuah aturan (by law enorcement), dengan cara :

1) Pencegahan yang di lakukan pelanggaran hak konseumen, lewat perizinan dan pengawasan melalui Hukum Adminstrai Negara (HAN).

2) Pencegahan adanya pelanggaraan undang-undang perlindungan konsumen, lewat sanksi pidana dan menjatuhkan hukuman, melalui Hukum Pidana.

3) Pemulihan atas Hak-hak, dengan cara memberikan sangksi untuk membayar kompensasi atau mengganti rugi, melalui Hukum Perdata .

\section{Perlindungan Jemaah Umrah Oleh Pihak Travel Penyelenggara Perjalanan Ibadah Umrah}

Saat ini perlindungan konsumen sangat diperhatikan oleh masyarakat, khususnya jemaah umroh dan haji yang resah akan Travel Penyelenggara Ibadah Umroh yang belum memberikan pelayanan terbaik bagi jemaahnya. Pemberian perlindungan hukum terhadap masyarakat terbagi menjadi dua hal, yaitu: ${ }^{9}$

\footnotetext{
${ }^{6}$ Satjipto Raharjo, Ilmu Hukum, (Bandung: PT. Citra Aditya Bakti, 200o), hlm.55

7 Setiono, Rule of Law (supermasi hukum), (Surakarta : Magister hukum program pascasarjan Uni. Sebelas maret, 2004) hlm.3

${ }^{8}$ Wahyu Sasongko, Ketentuan-ketentuan Pokok Hukum perlindungan konsumen, (Bandar lampung, Uni. Lampung, 2012) hlm.30

${ }^{9}$ Sudikno Mertokusumo, Penemuan Hukum, (Bandung : Citra Aditya Bakti, 2009) hlm. 41
} 
a. Adanya perlindungan Hukum Preventif, adalah sebuah bentuk perlindungan yang mana masyarakat mempunyai kesempatan untuk memberikan keberatan atau menyampatkan masukan ide, sebelum keputusan dari pemerintah berbentuk definitive (sudah pasti).

b. Bentuk perlindungan hukum Represif, maksudnya sebuah perlindungan hukum untuk jadikan cara menyelesaikan sengketa.

Negara memberikan perlindungan kepada masyarakatnya, dengan upaya memberikan hak-hak yang bisa didapatkan oleh warga Negara, sehingga tidak ada hak-hak yang merasa dihilangkan, dalam sebuah jurnal yang ditulis oleh R. La Porta dengan judul financial economics, memberikan penjelasan bahwa Negara memberikan perlindungan melalui dua sifat, yakni dengan sifat pencegahan (prohibited) dan sifat hukuman (sanction). Contoh perlindunganyang bersifat pencegahan yakni dengan membuat peraturan, sedangkan perlindungan yang bersifat hukuman yakni menegakan peraturan Adapun Proses perlindungan hukum yang nyata melalui institusi-institusi penegak hukum, diantaranya: kepolisian Republik Indonesia, Pengadilan, Kejaksaan dan lembaga-lembaga penyelesaian sengketa di luar pengadilan (Non-Litigasi).

Pemerintah sebagai pengatur instrument negara perlu memberikan pelayanan terbaik kepada masyarakat dalam berbagai penyelenggaraan kegiatan negara, termasuk dalam mengatur kebutuhan masyarakat terhadap perjalanan ibadah Umrah, sehingga diperlukan aturan hukum sebagai bentuk perlindungan terhadap jemaah yang akan beribadah Umrah oleh travel penyelenggara ibadah Umrah. Adapun bentuk-bentuk perlindungan tersebut diantaranya:

a. Kesehatan

b. Asuransi Jiwa

c. Perlindungan Kecelakaan

d. Pengurusan dokumen jemaah yang hilang selama perjalanan ibadah

Terkait dengan hilangnya dokumen perjalanan pemerintah mengeluarkan regulasi PMA No. 18 Tahun 2015 tentang Pnyelenggaraan Ibadah Umrah dalam Pasal 16 ayat (1) huruf b yang meyatakan bahwa PPIU wajib melakukan perlindungan Jemaah Umrah untuk pengurusan dokumen Jemaah yang hilang selama dalam perjalanan, diantara yang peting yakni Pasport, Visa, Surat kuning Bebas Meningitis, Surat Mahrom (jemaah wanita yang berusia di bawah 45 tahun dan tidak didampingi oleh suami maupun mahramnya ketika berangkat Umrah).

\section{Kendala-kendala Perlindungan Jemaah Umrah oleh Penyelenggara Perjalanan Ibadah Umrah.}

Regulasi diberlakukan oleh pemerintah untuk mengatur perjalanan Ibadah Umrah, dengan harapan memberikan pelayanan terbaik untuk masyarakat yang akan menunaikan ibadah umrah ke tanah suci. Namun dengan berjalannya waktu, muncul berbagai masalah baru yang menyebabkan harapan tersebut tidak tercapai sepenuhnya. Pasal 4 UUPK menyebutkan hak konsumen, dalam hal ini Jama'aah, ialah: hak atas kenyamanan, keamanan, dan keselamatan dan hak untuk mendapatkan advokasi, perlindungan, dan upaya penyelesaian sengketa perlindungan konsumen secara patut. Banyak kasus terjadi saat ini mulai dari Jemaah yang terlantar di Malaysia dan Jemaah yang terlantar Arab Saudi, karena kurang pelayanan dan melanggar perjanjian yang 
harus dipenuhi oleh pihak Travel. Hal tersebut hanya bagian kecil diantara travel-travel PPIU yang ada, sebab tidak memenuh hak-hak Jemaah.

Tidak seluruh travel penyelenggara haji dan umrah melakukan pelanggaran demikian. masih banyak travel yang baik pengelolaannya serta memberikan seluruh fasilitas yang menjadi hak Jemaah, sehingga Jemaah mendapatkan pelayanan yang baik. Namun untuk dapat memberikan pelayanan yang maksimal bagi pelanggan, travel yang sudah memiliki jam terbang tinggi pun, seperti MazQ Tours, Sanabil Barkah dan Multazam masih memiliki kendala dalam memberikan pelayanan dan perlindungan bagi jemaah. Berikut ini bentuk pelayan yang diberikan oleh pihak Travel:

1. Proses Pendaftaran Jemaah

Pelayanan yang diberikan oleh pihak Travel dilakukan dari mulai Jemaah datang ke kantor atau menghubungi pihak Travel untuk menanyakan program umrah. Pihak travel dengan penuh kehangatan memberikan informasi terkait program umrah yang ditawarkan, dan jika calon Jemaah tersebut berminat untuk menggunakan jasa Travel tersebut, maka pihak Travel akan memberikan fasilitas untuk membantu mengurus berkas-berkas Jemaah yang harus dipenuhi untuk persyaratan Umrah. Untuk syarat yang harus dipenuhi meliputi: ${ }^{10}$

a. Pasport, Masih berlaku minimal 7 bulan ke atas dihitung mulai hari $\mathrm{H}$ keberangkatan.

b. Pas Foto, foto terbaru berwarna, ukuran $4 \times 6$ sebanyak 5 lembar. Close up wajah $80 \%$ pakaian warna cerah dan latar belakang putih. Untuk wanita berkerudung tidak berkecamata dan laki-laki tidak berkecamata (tidak memakai Topi/peci);

c. Suntik Miningitis;

d. Fotocopy KTP;

e. Foto Copy Kartu Keluarga;

f. Akte Lahir;

g. Surat Nikah;

h. Surat Muhrim, dibuat untuk wanita yang usia dibawah 45 Tahun dan pergi tanpa pendamping. Biaya pembuatan surat Muhrim sebesar Rp.350.000/orang.

Jemaah yang mendaftar ke pihak Travel sangat bervariasi, mulai dari pegawai kantoran, guru, dosen, pengusaha bahkan petani, dengan berbagai latar belakang pendidikan. Hal tersebut membuat proses pengumpulan persyaratan yang dilakukan oleh pihak travel bermacam-macam perilakunya, ada yang mudah dalam proses pengumpulannya datanya dan juga ada yang kesulitan. permasalahan yang sering muncul pada tahapan ini, diantaranya: ${ }^{11}$

a. Akte berbeda dengan KTP. Masalah ini harus diurus di dinas catatan Sipil setempat.,

b. Buku nikah berbeda dengan KTP. Masalah ini harus diurus di KUA setempat.

Untuk efektifitas waktu, pihak travel membantu untuk menyelesaikan persyaratan-persyaratan tersebut, dengan tujuan memberikan pelayanan terbaik kepada Jemaah. Selanjutnya saat melakukan Booking tiket perjalanan dari jauh hari, yakni 2 (dua) bulan sebelum keberangkatan, diharuskan memberikan down payment (DP) atau uang panjar sebesar 3 (tiga) juta Rupiah/ orang kepada pihak maskapai. Sementara,

\footnotetext{
${ }^{10}$ Surat ketentuan dan persyaratan Umrah 2017/2018 Travel Dago Wisata

${ }^{11}$ Hasil wawancara dengan staf Sanabil Barkah Bandung (terlampir)
} 
untuk pelunasan dilakukan paling lambat dalam waktu 1 (satu) bulan sebelum keberangkatan sesuai dengan jumlah jemaahyang dibooking (minimal 20-30 orang perbooking). Jika pelunasan tidak terpenuhi maka uang DP awal akan hangus.

2. Proses Perjalanan Indonesia menuju Arab Saudi

Perlindungan yang dilakukan oleh pihak penyelenggara ibadah Umrah dilanjutkan hingga menuju Arab Saudi, namun saat perjalanan berlangsung ada beberapa kasus yang sering terjadi dan ditemui, diantaranya sebagai berikut:

a. Di perjalanan menuju bandara Internasional Jakarta.

Perjalanan menuju bandara terkendala kondisi jalanan yang tidak menentu. Selain itu seperti kejadian alam, cuaca buruk, bahkan kecelakaan mempengaruhi aktifitas berkendara dari pihak pengendara yang disediakan oleh travel Umrah dan haji, dan juga yang terpenting dari semua ini adalah padatnya volume kendaraan yang ada sehingga menimbulkan kemacetan.

b. Penerbangan terlambat (delay). Perlindungan yang diberikan saat terjadi keterlambatan penerbangan dari Jakarta menuju Jeddah, atau Jakarta menuju Malaysia, Malaysia menuju Jeddah akibat cuaca buruk, kerusakan pesawat, dan alasan lainnyayang terjadi dari pihak maskapai, merupakan tanggung jawab maskapai, dan berkewajiban untuk memberikan kompensasi kepada jemaah sesuai dengan durasi waktu keterlambatan.

c. Kendala yang dihadapi di Arab Saudi. Saat tiba di Arab Saudi, Jemaah umrah yang akan melaksankaan ibadah masih harus menyesuaikan diri dengan lingkungan sekitar yang belum terbiasa, sehingga menyebabkan adanya perhatian khusus untuk melihat keberadaan para jemaah tersebut. misalnnya saja jemaah tersesat ketika akan kembali ke penginapan dari Masjidil Haram atau Masjid Nabawi karena memisahkan diri dari rombongan Penanganan yang dilakukan oleh pihak travel untuk mengantisipasi keadaan ini adalah dengan memberikan petunjuk arah kepada jemaah. Terkhusus kepada jemaah yang memerlukan pendampingan lebih seperti orang tua atau anak-anak.

\section{Pengawasan Pemerintah Terhadap Implementasi Perlindungan Jemaah oleh Penye- lenggara Perjalanan Ibadah Umrah}

Keinginan untuk menunaikan salah satu ibadah wajib ini mendorong banyak orang untuk menabung dalam waktu yang tidaklah sebentar, sementara disisi lain sebagian orang melihat hal ini sebagai peluang bisnis yang cukup menjanjikan banyak sekali agen perjalanan atau travel agency yang menyediakan jasa berupa paket perjalanan wisata religi atau yang biasa disebut sebagai paket perjalanan Haji atau Umrah. Di satu sisi hal ini membantu memenuhi kebutuhan religi orang lain, namun juga diiringi dengan keinginan mengambil keuntungan yang berujung pada lahirnya sistem pemasaran atau marketing.

Pemasaran adalah suatu fungsi organisasi dan serangkaian proses untuk menciptakan, mengkomunikasikan, dan memberikan nilai kepada pelanggan dan untuk mengelola hubungan pelanggan dengan cara menguntungkan organisasi dan pemangku kepentingan. ${ }^{12}$ Sebagai pelanggan, adanya hak-hak Perlindungan sebagai Konsumen

12 Philip Kotler dan Kevin Lane Keller, Manajemen Pemasaran Edisi Ketiga belas, (Jakarta; Erlangga, 2009), hlm. 5 
(Jemaah Umrah) sangatlah diperhatikan sebagai bentuk kepuasan untuk jemaah yang akan menunaikan ibadah haji ataupun umrah.

Pengawasan dan pengendalian penyelenggaraan umrah merupakan salah satu tugas Kementerian Agama sesuai dengan Peraturan Menteri Agama Nomor 18 Tahun 2015 Pasal 20 Ayat (1) dan Ayat (2) disebutkan bahwa;

(1) Pengawasan dilakukan oleh Direktur Jenderal atas nama Menteri.

(2) Pengawasan sebagaimana dimaksud pada ayat (1), meliputi pengawasan terhadap rencana perjalanan, kegiatan operasional pelayanan Jemaah, ketaatan dan/atau penertiban terhadap ketentuan peraturan perundangundangan.

Saat ini, peraturan baru kementrian Agama yang dikeluarkan pada tahun 2018 yakni Peraturan Menteri Agama No.8 Tahun 2018 sebagai Revisi Peraturan Menteri Agama No.18 Tahun 2015. Dalam peraturan ini terdapat sebuah sistem yang dibangun untuk menguatkan pengawasan yang berguna sebagai bentuk perlindungan konsumen berbentuk pengawasan intensif terhadap segala pihak, baik itu jemaah, pihak travel dan penyelenggara ibadah umrah dan haji.Sebelum peraturan ini direvisi, ada beberapa masalah yang terjadi karena, salah satunya kurang pengawasan dari pihak terkait. Beberapa diantaranya adalah:

1. Tidak adanya pengawasan berkala terhadap travel penyelenggara ibadah umrah dan pengawasan dari pusat bersifat Pasif, maksudnya pemerintah akan bertindak ketika ada laporan dari Jemaah. Sehingga menyebabkan terjadinya kasuskasus dari pihak travel PPIU yang merugikan jemaah ibadah Umrah.

2. Undang-undang Penyelenggaraan ibadah haji dan peraturan menteri Agama Nomor 18 tahun 2015 belum mengatur tentang kewajiban PPIU untuk menjamin kepastian keberangkatan jemaah umrah dan standar biaya umrah.

3. Lemahnya pengawasan menteri Agama terhadap penyelenggara ibadah umrah. Kelemahan itu misalnya dapat dilihat dari belum tersedianya data jemaah dan biro penyelenggara ibadah umrah yang tercatat dengan baik di kementerian agama.

4. Calon jemaah umrah tidak memiliki pengetahuan dan pengalaman yang sama dalam memilih biro perjalanan umrah atau dalam hal in adalah PPIU, dikarenakan kurangnya akses media publikasi kepada masyarakat mengenai informasi biro perjalanan umrah. Terkhusus untuk jangkauan wilayah pedesaan.

Peraturan Menteri Agama baru tersebut mengatur tentang biaya ibadah umrah (BPIU) referensi, yaitu biaya rujukan dalam penyelenggaraan ibadah umrah. BPIU referensi ini ditetapkan oleh menteri agama secara berkala. Jika PPIU menetapkan BPIU dibawah BPIU Referensi, PPIU tersebut wajib melaporkan secara tertulis kepada pemerintah yakni Direktur Jenderal Penyelenggara Haji dan Umrah selain itu, PMA tersebut juga mengatur kewajiban PPIU untuk memberangkatkan jemaah umrah paling lambat 6 bulan setlah jemaah mendaftar sebagai jemaah umrah.

Pengaturan lainnya adalah mengenai kewajiban PPIU untuk melaporkan jemaah yanag telah trdaftar kepada direktorat jenderal penyelenggaraan ibadah haji dan umrah melalui sitem pelaporan elektronik. Sistem ini dinamakan dengan SIPATUH, singkatan dari Sistem Informasi Pengawasan Terpadu Umrah dan Haji Khusus yang dibangun berbasis elektronik untuk memberikan pelayanan dalam sebuah sistem yang terintegrasi. SIPATUH dikembangkan dalam rangka memperkuat pengawasan penyelenggaraan 
umrah di Indonesia dan perluasan cakupan pengawasan sejak pendaftaran sampai kepulangan. Sistem ini memuat sejumlah informasi, di antaranya: ${ }^{13}$

a. Pendaftaran jemaah umrah,

b. Paket perjalanan yang ditawarkan PPIU,

c. Harga paket,

d. Pemantauan penyediaan tiket yang terintegrasi dengan maskapai penerbangan, dan

e. Pemantauan akomodasi yang terintegrasi dengan sistem muassasah (badan atau yayasan yang didirikan sebagai pengganti syekh jemaah Haji di Makkah) di Arab Saudi.

Selain itu, SIPATUH juga memuat alur pemesanan visa yang terintegrasi dengan Kedutaan Besar Saudi Arabia, validasi identitas jemaah yang terintegrasi dengan Dukcapil dan pemantauan keberangkatan dan kepulangan yang terintegrasi dengan Imigrasi.

Melalui SIPATUH, jemaah akan memperoleh nomor registrasi pendaftaran sebagai bukti proses pendaftaran yang dilakukan sesuai peraturan. Artinya, proses akhir pendaftaran adalah keluarnya nomor registrasi umrah (sejenis nomor porsi dalam pendaftaran ibadah haji). Dengan nomor registrasi ini, jemaah dapat memantau proses persiapan keberangkatan yang dilakukan oleh PPIU, mulai dari pengadaan tiket, pemesanan akomodasi, hingga penerbitan visa. Melalui sistem ini jemaah dapat memonitor seluruh proses pengurusan perjalanan ibadah umrah sejak pendaftaran hingga kembali ke Tanah Air.

\section{Penutup}

Bentuk-bentuk perlindungan yang harus diberikan oleh pihak penyelengggara perjalanan ibadah umrah mencakup semua aspek yang dibutuhkan oleh jemaah, yakni: Kesehatan, Asuransi jiwa, Perlindungan kecelekaan, Pengurusan dokumen jemaah yang hilang selama perjalanan beribadah. Jemaah akan merasa bahwa dirinya akan terlindungi dari hal-hal yang tidak diinginkan, hal tersebut tertuang dalam Peraturan Menteri Agama Nomor 8 Tahun 2018. Namun dalam proses pelaksanaan Asuransi, masih ada Travel yang belum memakai Jasa Asuransi, yang seharusnya didapatkan oleh Jemaah.

Kendala yang dialami oleh pihak travel PPIU dalam perlindungan jemaah umrah yakni keterbatasan dana yang dimiliki, karena travel berlomba-lomba untuk mendapatkan banyak jemaah dengan harga murah, sehingga tidak alokasi dana untuk asuransi jemaah,dan tidak ada l'tikad baik dari pihak travel untuk mengasuransikan jemaah umrah.

Pengawasan berdasarkan Peraturan Menteri Agama Nomor 8 Tahun 2018 Tentang penyelenggaraan Ibadah Umrah, masih dirasakan belum memenuhi aspek perlindungan untuk jemaah. Tidak adanya pengawasan berkala terhadap travel penyelenggara ibadah umrah dan pengawasan dari pusat bersifat pasif, maksudnya pemerintah akan bertindak ketika ada laporan dari Jemaah. Sehingga menyebabkan terjadinya kasus-kasus dari pihak travel PPIU yang merugikan jemaah ibadah Umrah.

${ }^{13}$ http://ppa.ub.ac.id/wp-content/uploads/2012/01/ISTILAH-DALAM-HAJI-NET. diakses jam 22.45, 9 
Hal yang harus diupayakan ialah terkait Regulasi yang sudah ada yang mengatur perlindungan perjalanan umrah, selain SIPATUH yang sudah dilaksanakan, untuk lebih memproteksi jemaah maka Kementerian Agama harus lebih menegaskan tentang kewajiban asuransi untuk setiap travel mendaftarkan jemaahnya agar diasuransikan.

Setiap informasi dari kementerian terkait travel penyelenggara perjalanan ibadah umrah, dipastikan agar sampai ke masyarakat, terkhusus dibagian pedesaan yang ada di daerah-daerah yang saat ini hanya dipanggil perwakilan saja perkecamatan sehingga informasi tidak menyeluruh terkait perjalan ibadah umrah baik itu memilih travel dan lain sebagainya sehinga informasi yang didaptkan bisa sama. Dikarenakan pada peneliti saat ini mendapati bahwa kurangnya publikasi, sehingga tidak banyak informsi yng didapat oleh jemaah umrah.

\section{Daftar Pustaka}

Hamidi, Jazim dan Mustafa Lutfi. 2009. Hukum Lembaga Kepresidenan Indonesia. Malang: Alumni.

Kotler, Philip dan Kevin Lane Keller. 2009. Manajemen Pemasaran Edisi Ketiga Belas. Jakarta: Erlangga.

Mertokusumo, Sudikno. 2009. Penemuan Hukum. Bandung: Citra Aditya Bakti.

Raharjo, Satjipto. 2000. Ilmu Hukum. Bandung: PT. Citra Aditya Bakti.

Sasongko, Wahyu. 2012. Ketentuan-ketentuan Pokok Hukum Perlindungan Konsumen. Bandar Lampung: Universitas Lampung.

Setiono. 2004. Rule of Law Supermasi Hukum. Surakarta: Universitas Surakarta.

Undang-Undang Dasar Negara Republik Indonesia Tahun 1945 Pasal 1 ayat (3).

Undang-undang No 10 tahun 2009 tentang Kepariwisataan

Undang-undang No 8 Tahun 1999 tentang Perlindungan Konsumen 
58 | Asy-Syari'ah Vol. 20 No. 1, Agustus 2018 